\title{
EFFECT OF LARGE DIETARY DOSES OF $\beta$-CAROTENE ON PLASMA RETINOID AND $\beta$-CAROTENE LEVELS AND ON PROGESTERONE PRODUCTION IN THE GRANULOSA CELLS OF JAPANESE QUAIL
}

\author{
A. PuszTAi, Gabriella ÁgotA and L. BÁRdos* \\ Department of Animal Physiology and Health, Gödöllö Agricultural University, \\ H-2103 Gödöllö, Páter K. u. 1, Hungary
}

(Received March 26, 1999; accepted June 24, 1999)

\begin{abstract}
An experiment was conducted to study the effect of large-dose $\beta$-carotene supplementation on blood retinoid and $\beta$-carotene levels as well as on the progesterone secretion of the granulosa cells in Japanese quail. Laying quails were assigned to three dietary groups. The control group (Group C) received the basal diet (laying feed containing $9000 \mathrm{IU}$ vitamin $\mathrm{A} / \mathrm{kg}$ ). In the treated groups (Groups $\mathrm{BC} 1$ and $\mathrm{BC} 2$ ) the basal diet was supplemented with $10^{2}$ and $10^{3} \mathrm{mg} / \mathrm{kg} \beta$ carotene $(\mathrm{BC})$, respectively. At the end of the two-week feeding period, 10 birds from each group were euthanised. Blood samples were analysed for retinol, retinyl palmitate and $\beta$-carotene concentrations. Granulosa cells were isolated from ovarian follicles $\left(\mathrm{F}_{1}\right.$ and $\left.\mathrm{F}_{2}\right)$, and $\mathrm{PMSG}$-induced in vitro progesterone $\left(\mathrm{P}_{4}\right)$ secretion was measured. Similar retinol concentrations were found in both $\beta$ carotene supplemented groups, indicating saturation of the retinol-transporting system. $\beta$-carotene supplementation was accompanied by hypercarotenaemia, but did not increase the retinyl palmitate levels in the blood. PMSG-induced $\mathrm{P}_{4}$ production of the granulosa cells decreased significantly in Groups BC1 and BC2 in a dose-dependent manner.
\end{abstract} quail

Key words: $\beta$-carotene, retinoids, progesterone, granulosa cell, Japanese

Since the 1980s, naturally occurring compounds and a growing number of synthetic compounds with more or less vitamin A activity have been called ret inoids due to similarities in their structure and effects. The term 'vitamin A' is correct if used as a general term (effect, deficiency, etc.). Wherever possible, the name of the molecule should be given: retinol, retinyl ester, e.g. palmitate, etc. (Goodman, 1987). There are manifold explanations for the metabolic and/or $\mathrm{r}$ eproductive symptoms resulting from the deficiency of certain retinoids. These symptoms can be explained by general influences such as effects exerted on the

*Corresponding author; E-mail: lbardos@fau.gau.hu 
synthesis of membrane glycoproteins which participate in the differentiation of the epidermal and connective tissue (Sporn, 1977), by antioxidant functions similar to those of some tocopherols and carotenoids (Livrea and Packer, 1994), and by retinoid influences aimed at the preservation of biological membranes. A number of studies indicate an interrelation between retinoids and the endocrine system (Galdieri and Nistico, 1994; Huang et al., 1985). After binding to rece ptors, active retinoids (e.g. retinoic acid) directly or indirectly stimulate the e xpression of specific genes (Moore, 1990; Hashimoto, 1991). They have a specific function in the gene expression of microsomal cytochrome $\mathrm{P}_{450}$ oxidases (Hauswirth and Bizuela, 1976), which take part in many steps of the biosynthesis of cholesterol and steroid hormones (Murray et al., 1991). As a result of these discoveries over the last few years, retinoids have been placed in the category of hormones (Wolf, 1990).

The retinoid metabolism of avian species differs from that of mammals in several respects. Rats kept on a vitamin A deficient diet supplemented with ret inoic acid grow appropriately but become blind and infertile in both sexes. In chicks, appropriate growth can be found, too, and both cocks and hens remain fertile. However, embryonic death will occur already on the second day of inc ubation (Thompson et al., 1969).

In the ovary, the synthesis of steroid hormones takes place in special cells: the granulosa, external and internal cells of the theca. These cell layers form the wall of the follicle. During follicular maturation, granulosa cells synthesise pr ogesterone in birds. The primary source of ovarian progesterone is the largest and the second largest preovulatory follicle ( $\mathrm{F}_{1}$ and $\mathrm{F}_{2}$, respectively).

In this experiment, Japanese quails were fed large doses of $\beta$-carotene (BC). The effects of supplementation on the retinol, retinyl palmitate and BC concentration of the blood as well as on progesterone $\left(\mathrm{P}_{4}\right)$ secretion of the granulosa cells in vitro were studied.

\section{Materials and methods}

\section{Experimental animals and design}

Three groups (with 10 birds in each group) were formed from 10-weekold Japanese quail hens. The control group (C) was fed basal feed containing 9000 IU vitamin A $/ \mathrm{kg}$ feed. The basal feed of the treated groups (Groups BC1 and $\mathrm{BC} 2$ ) was supplemented with $\beta$-carotene (BC, Table 1). After two weeks of feeding, the birds were killed by bleeding. Retinoid, $\mathrm{BC}$ and lipid content of the blood plasma as well as progesterone $\left(\mathrm{P}_{4}\right)$ secretion of granulosa cells isolated from the ovarian follicles were determined. 
Table 1

Experimental design and treatments

\begin{tabular}{cccc}
\hline \multirow{2}{*}{ Treatment } & \multicolumn{3}{c}{ Groups $^{*}$} \\
\cline { 2 - 4 } & $\mathrm{C}$ & $\mathrm{BC} 1$ & $\mathrm{BC} 2$ \\
\hline $\mathrm{RA}(\mathrm{IU} /$ feed kg) & 9000 & - & - \\
$\mathrm{BC}(\mathrm{mg} /$ feed $\mathrm{kg})$ & - & 100 & 1000 \\
\hline
\end{tabular}

${ }^{*}$ Group $\mathrm{C}=$ control, basal diet; Groups $\mathrm{BC}=$ basal diet supplemented with $\beta$-carotene; $\mathrm{RA}=$ retinyl acetate; $\mathrm{BC}=\beta$-carotene

\section{$\beta$-carotene used for the experiment}

To adjust the required doses of $\mathrm{BC}$, Rovimix- $\beta$-carotene $10 \%$ (HoffmannLa Roche, Basle) starch-coated preparation was used for supplementation.

\section{Cell preparations}

The granulosa layers were separated from the $F_{1}$ and $F_{2}$ follicles of the ovaries. After several cycles of washing (MEM Eagle, $20 \mathrm{mM}$ HEPES, $0.1 \%$ BSA fra ction $\mathrm{V}, \mathrm{N}^{\circ} \mathrm{A}-8022$, Sigma, St. Louis, $50 \mathrm{mg} / \mathrm{L}$ gentamicin sulphate, 50,000 IU/L penicillin, $50 \mathrm{mg} / \mathrm{L}$ streptomycin) the cells were dispersed by digestion with coll agenase (Collagenase type IA, $\mathrm{N}^{\circ} \mathrm{C}-9891$, Sigma, St. Louis). This process was fo 1lowed by several cycles of washing, centrifugation and cell counting (by Trypan Blue exclusion method, no. of live cells $>90 \%$ ). The final number of cells was adjusted to $10^{5}$ cells $/ 0.8 \mathrm{~mL}$ with antibiotic-free MEM. Subsequently the suspe $\mathrm{n}$ sion was divided into plastic tubes $(0.8 \mathrm{~mL} /$ tube $)$ which were treated with 0.5 $\mathrm{IU} / \mathrm{mL}$ PMSG (Folligon, Intervet) and incubated $\left(37^{\circ} \mathrm{C}, 5 \mathrm{~h}\right)$.

\section{Analytical methods}

ELISA. The progesterone concentrations of the incubates of granulosa cells were measured by an ELISA technique developed at the Agricultural Bi otechnology Centre (ABC, Gödöllö, Hungary) (Siklódi et al., 1995).

High-performance liquid chromatography (HPLC). Measurement of plasma retinoid (retinol, Rol; retinyl palmitate, RP) concentrations was carried out by isocratic adsorption HPLC (Biesalski et al., 1986). The modifications and adaptations of the method for $\mathrm{BC}$ analysis were published previously (Kerti and Bárdos, 1999).

\section{Statistical analysis}

Statistical analysis was performed on individual data obtained from an alytical results and presented as means and \pm SD. Correlations were calculated by 
the Pearson-Braevis formula. Differences between groups and treatments were evaluated by Student's $t$-test and considered as significant if $\mathrm{p}<0.05$.

The animal experiment was carried out with consent of the Animal Exper iments Board of the University.

\section{Results}

The blood concentration of Rol was significantly higher $(p<0.001)$ in the groups given BC supplementation than in Group C. The RP concentration of the blood increased significantly in Group BC2 $(p<0.05)$, compared with the values measured in Group C (Table 2). Plasma BC level was in close correlation with $\mathrm{BC}$ supplementation $(\mathrm{r}=+0.7, \mathrm{p}<0.05)$. $\mathrm{PMSG}$-induced in vitro $\mathrm{P}_{4}$ production of granulosa cells was decreased in the BC-supplemented groups. The decrease seemed to be dose dependent (Table 2).

Table 2

Blood retinoid and $\beta$-carotene levels $(\mu \mathrm{g} / \mathrm{L})$

and in vitro progesterone secretion $(\mathrm{ng} / \mathrm{mL})$ of granulosa cells $(\bar{x} \pm \mathrm{SD})$

\begin{tabular}{lccc}
\hline Parameters $^{* *}$ & \multicolumn{3}{c}{ Groups $^{*}$} \\
\cline { 2 - 4 } & $\mathrm{C}$ & $\mathrm{BC} 1$ & $\mathrm{BC} 2$ \\
\hline Rol & $692 \pm 224$ & $1220 \pm 255^{\mathrm{c}}$ & $1394 \pm 166^{\mathrm{c}, \mathrm{x}}$ \\
$\mathrm{RP}$ & $848 \pm 880$ & $1200 \pm 204$ & $1713 \pm 179^{\mathrm{a}}$ \\
$\mathrm{BC}$ & $60 \pm 28$ & $551 \pm 210^{\mathrm{c}}$ & $1157 \pm 364^{\mathrm{c}, \mathrm{z}}$ \\
$\mathrm{P}_{4}$ & $79.0 \pm 4.1$ & $57.1 \pm 33.0$ & $27.9 \pm 2.7^{\mathrm{c}, \mathrm{z}}$ \\
\hline
\end{tabular}

${ }^{*}$ Group $\mathrm{C}=$ control, basal diet; Groups $\mathrm{BC}=$ basal diet supplemented with $\beta$-carotene; ${ }^{* *}$ Rol $=$ retinol, $\mathrm{RP}=$ retinyl palmitate, $\mathrm{BC}=\beta$-carotene, $\mathrm{P}_{4}=$ progesterone; Values of significance $(\mathrm{p} \leq 0.05$; $\mathrm{p} \leq 0.01$ and $\mathrm{p} \leq 0.001)$ ${ }^{\mathrm{a}}$ and ${ }^{\mathrm{c}}$ between control and treated groups; ${ }^{\mathrm{x}}$ and ${ }^{\mathrm{z}}$ between treated groups

\section{Discussion}

The plasma vitamin A level (both Rol and RP) of Japanese quails fed high dietary doses of $\mathrm{BC}$ showed a significant increase by the $2^{\text {nd }}$ week of treatment. In Group BC1 no increase of RP level was found, but in Group BC2 a slight i ncrease did occur (Table 2). The retinyl ester fraction (RP) indicates intensive a bsorption from the intestine (Goodman and Blaner, 1984). Elevation of the level of retinyl esters in the blood is a clinical laboratory diagnostic indicator of $\mathrm{h} \mathrm{y}$ pervitaminosis A (Smith and Goodman, 1976). In this experiment no clinical symptoms of hypervitaminosis A were detected, probably due to the short period of supplementation. From these results it can be concluded that the transform a- 
tion of $\mathrm{BC}$ into vitamin A was intensive in Japanese quail. When increasing the dose of $\mathrm{BC}$ the efficiency of transformation decreased in the same manner as had been found in chicks (Brubacher and Weiser, 1985). This is one of the possible explanations why excess $\mathrm{BC}$ causes only carotenaemia and does not pose a risk of hypervitaminosis A.

Ovarian granulosa cells have several types of ion channels, e.g. potassium, chloride and calcium. The ion milieu is a very important factor during in vitro studies. In the hen, luteinizing hormone induced $\mathrm{P}_{4}$ production of ovarian granulosa cells is inhibited when chloride ions are removed from the medium (Chiang et al., 1997). In the present experiment all ions in the MEM were within the re commended physiological range.

The results of this experiment indicate that the ovarian steroid metabolism of Japanese quails is affected by BC treatment. This influence was detected in in vitro $\mathrm{P}_{4}$ production occurring as a response to PMSG stimulation of granulosa cells. Vitamin A stimulates the $\mathrm{P}_{4}$ secretion of granulosa cells in vitro (Talavera and Chew, 1988). Taking into account that steroid hormones are secreted at the rate of their production, it seems reasonable to suppose that the increased $\mathrm{P}_{4}$ secretion was the result of an increased synthesis. According to some hypotheses, retinol plays a part in the transformation of pregnenolone into $\mathrm{P}_{4}$ (Ganguly et al., $1980)$. At that step the enzymes $\Delta 5-3 \beta$-hydroxysteroid-dehydrogenase and $\Delta 5$ $3 \beta$-isomerase are the most important in birds.

In certain mammals $\mathrm{BC}$ is known to have a retinoid-independent role in reproduction, in addition to its antioxidant and provitamin functions. There are reports in the literature that $\mathrm{BC}$ affects the reproductive functions of cows in a manner independent of vitamin A (Lotthammer and Ahlswede, 1977; Lotthammer, 1978). In cows, the increase of dietary $\mathrm{BC}$ was found to stimulate in vitro $\mathrm{P}_{4}$ production of isolated luteal cells (Pethes et al., 1985).

The pattern of in vitro steroidogenesis in Japanese quail granulosa cells is similar to that described for the chicken (Etches and Cunningham, 1976) and tu rkey (Hammond et al., 1981). Quantitative differences in the capacity of steroid ogenesis between developing and mature follicles are more striking in the quail (Asem et al., 1985). In this in vitro experiment, PMSG-stimulated granulosa cells isolated from Japanese quails having different blood retinoid and/or BC levels as a result of dietary $\mathrm{BC}$ supplementation showed differences in $\mathrm{P}_{4}$ production (Table 2). Although the efficiency and thus the vitamin A potential of $\mathrm{BC}$ were $\mathrm{d}$ epressed (Brubacher and Weiser, 1985), extremely large doses of BC resulted in an unexpected influence on in vitro $\mathrm{P}_{4}$ secretion of the granulosa cells. The rate of $\mathrm{P}_{4}$ secretion was inversely proportional to the dietary doses and the plasma $\mathrm{BC}$ level, respectively. Both levels of BC supplementation resulted in an approx imately equal plasma Rol level, suggesting that the RBP-TTR transport protein system was fully saturated. BC is known to have only a single transport mech anism which is of low specificity and dependent on the metabolism of plasma 
lipoproteins (Schweigert et al., 1993). This is supported by previous results, i.e. that an increase in the level of RP belonging to the fraction of plasma lipopr oteins caused a decrease in plasma BC (Kerti and Bárdos, 1999), and that different BC doses resulted in different plasma BC levels (Kerti and Bárdos, 1997) in Japanese quail.

Although $\mathrm{BC}$ as a vitamin A precursor has never been reported to exert any harmful effect on the functioning of the animal organism, the results of this study show that extreme hypercarotenaemia can depress the $\mathrm{P}_{4}$ production of granulosa cells.

\section{Acknowledgements}

This work was supported by grants from the Hungarian Scientific Research Fund (OTKA-T-6471) and the Higher Education Research and Development Program (FKFP0473) to L. B. and by a PhD fellowship from the Biological Bases of Animal Breeding (Gödöllö University) to Á. G. The authors thank Ms Krisztina Karchesz and Mr Béla Barlai for their excellent assistance.

\section{References}

Asem, E., Marrone, B. L. and Hertelendy, F. (1985): Steroidogenesis in ovarian cells of the Japanese quail (Coturnix coturnix japonica). Gen. Comp. Endocrinol. 60, 353-360.

Biesalski, H., Greiff, H., Brodda, K., Hafner, G. and Bassler, K. H. (1986): Rapid determination of vitamin A (retinol) and vitamin E ( $\alpha$-tocopherol) in human serum by isocratic adsorption HPLC. Internat. J. Vit. Nutr. Res. 56, 319-327.

Brubacher, G. B. and Weiser, H. (1985): The vitamin A activity of $\beta$-carotene. Internat. J. Vit. Nutr. Res. 55, 5-15.

Chiang, M., Strong, J. A. and Asem, E. K. (1997): Luteinizing hormone activates chloride currents in hen ovarian granulosa cells. Comp. Biochem. Physiol. 116A, 361-368.

Etches, R. J. and Cunningham, F. J. (1976): The interrelationship between progesterone and luteinizing hormone during the ovulation cycle of the hen (Gallus domesticus). J. Endocrinol. 71, 51-58.

Galdieri, M. and Nistico, L. (1994): Retinoids regulate gonadotropin action in cultured rat Sertoli cells. Biol. Reprod. 50, 171-177.

Ganguly, J., Rao, M. R. S., Murthy, S. K. and Sandra, K. (1980): Systemic mode of action of vitamin A. Vitam. Hormones 38, 1-56.

Goodman, D. S. (1987): Retinoids and retinoid-binding proteins. In: Gehring, W., Goodman, D., Herskowitz, I., Hynes, R., Matthews, B., Schwartz, R., Sharp, P. and Wang, J. (eds) The Harvey Lectures, Ser. 81, Alan R. Liss, Inc., New York. pp. 111-132.

Goodman, D. S. and Blaner, W. S. (1984): Biosynthesis, absorption, and hepatic metabolism of retinol. In: Sporn, M. B., Roberts, A. B. and Goodman, D. S. (eds) The Retinoids. Vol. 2. Academic Press, New York.

Hammond, R. W., Koelkebeck, K. W., Scanes, C. G., Biellier, H. V. and Hertelendy, F. (1981): Plasma prostaglandin, LH and progesterone levels during the ovulation cycle of turkey (Meleagris gallopavo). Gen. Comp. Endocrinol. 44, 400-403.

Hashimoto, Y. (1991): Retinoids and their nuclear receptors. Cell. Biol. Rev. 25, 209-235. 
Hauswirth, J. W. and Bizuela, B. S. (1976): The differential effects of chemical carcinogens on vitamin A status and on microsomal drug metabolism in normal and vitamin A-deficient rats. Cancer Res. 34, 1941-1946.

Huang, H. S. F., Dyrenfurth, I., Gunsalus, G. L. and Hembref, W. C. (1985): Effect of vitamin A deficiency upon gonadotropin response to gonadotropin-releasing hormone. Biol. Reprod. 33, 1176-1187.

Kerti, A. and Bárdos, L. (1997): Effect of different amounts of vitamin A equivalent $\beta$-carotene on the hatchability of Japanese quail eggs (in Hungarian). Állattenyésztés és Takarmányozás 46, 515-524.

Kerti, A. and Bárdos, L. (1999): Storage of retinoids and beta-carotene in the genital organs of Japanese quail. Acta Vet. Hung. 47, 95-101.

Livrea, M. A. and Packer, L. (1994): Vitamin A as an antioxidant in vitro and in vivo. In: Livrea, M. A. and Vidali, G. (eds) Retinoids: From Basic Science to Clinical Applications. Birkhäuser Verl., Basle. pp. 293-303.

Lotthammer, K.-H. and Ahlswede, L. (1977): Untersuchungen über eine spezifische, Vitamin Aunabhängige Wirkung des $\beta$-Carotins auf die Fertilität des Rindes. Dtsch. Tierärtzl. Wschr. 84, 220-226.

Lotthammer, K-H. (1978): Importance of $\beta$-carotene for bovine fertility - original researches. In: Lotthammer, K-H., Cooke, B. C. and Friesecke, H. (eds) Animal Nutrition Events. Hoffman-La Roche \& Co. AG, Basle. pp. 5-44.

Moore, D. D. (1990): Diversity and unity in the nuclear hormone receptors; a terpenoid receptor superfamily. New Biologist 2, 100-105.

Murray, M., Cantrill, E., Martini, R. and Farrell, G. C. (1991): Increased expression of cytochrome P450 IIIA2 in male rat liver after dietary vitamin A supplementation. Arch. Biochem. Biophys. 286, 618-624.

Pethes, G., Horváth, E., Kulcsár, M., Huszenicza, Gy., Somorjai, Gy., Varga, B. and Haraszti, J. (1985): In vitro progesterone production of corpus luteum cells of cows fed low and high levels of beta-carotene. Zbl. Vet.-med. A 32, 289-296.

Schweigert, F. J., Gürtler, H. and Anke, M. (1993): Comparative aspects of parenteral $\beta$-carotene administration to cows and goats. Internat. J. Vit. Nutr. Res. 63, 317-318.

Siklódi, B., Barna-Vetró, I. and Solti, L. (1995): Latent immunization to produce high-affinity monoclonal antibodies to progesterone. Hybridoma 14, 79-84.

Smith, F. R. and Goodman, D. S. (1976): Vitamin A transport in human vitamin A toxicity. N. Engl. J. Med. 294, 805-808.

Sporn, M. B. (1977): Retinoids and carcinogenesis. Nutr. Rev. 35, 65-69.

Talavera, F. and Chew, B. P. (1988): Comparative role of retinol, retinoic acid and beta-carotene on progesterone secretion by pig corpus luteum in vitro. J. Reprod. Fert. 82, 611-615.

Thompson, J. N., Howell, J. M., Pitt, G. A. J. and McLaughlin, C. I. (1969): The biological activity of retinoic acid in the domestic fowl and the effects of vitamin A deficiency on the chick embryo. Br. J. Nutr. 23, 471-490.

Wolf, G. (1990): Recent progress in vitamin A research: nuclear retinoic acid receptors and their interaction with gene elements. J. Nutr. Biochem. 1, 284-289. 